\title{
PHONOLOGICAL CORRESPONDENCE BETWEEN INDONESIAN AND MADURESE LANGUAGE : A STUDY OF ETHNOGRAPHY OF COMMUNICATION
}

\author{
Anita Rahmah Dewi ${ }^{1}$, Siti Aisah ${ }^{2}$ \\ Universitas Billfath Lamongan ${ }^{1,2}$
}

INFO ARTIKEL

Diterima: 25-12-2020

Disetujui: 4-2-2021

\section{Kata kunci: \\ Madurese; \\ variety \\ language; \\ phonological \\ correspondence}

\begin{abstract}
ABSTRAK
Abstract:

Vernacular or local language as general used by several communities which is admitted by cultural symbol of those communities. Such as Madurese Language. Madurese language is interesting to be analyzed due to the various dialect which available. Therefore, this study aims to investigate the language variety which exists in Madurese language. It also elaborates the phonological correspondence which is occurred between Indonesian and Madurese language. This study uses ethnography of communication approach that is formulated by Dell Hymes. Furthermore, to conduct this study, the library research method is applied to serve the data. This study finds out some different dialects and speech levels which exist in Madurese language. subsequently, some various phonological correspondences also occur between Indonesian and Madurese language.
\end{abstract}

\begin{abstract}
Abstrak:
Bahasa daerah merupakan bahasa yang pada umumnya digunakan oleh sekelompok masyarakat untuk menunjukkan sebuah simbol kebudayaan masyarakat, seperti Bahasa Madura. Macam-macam dialek yang terkandung dalam Bahasa Madura sangat menarik untuk dikaji, oleh karena itu, penelitian ini bertujuan untuk mengetahui ragam bahasa yang muncul dalam bahasa Madura. Selain itu, penelitian ini juga menjelaskan korespondensi fonologis yang terjadi antara Bahasa Indonesia dan Bahasa Madura. Penelitian ini menggunakan pendekatan etnografi komunikasi yang dirumuskan oleh Dell Hymes. Selanjutnya, untuk melakukan penelitian ini digunakan metode studi pustaka untuk menyajikan data. Penelitian ini ini menemukan beberapa perbedaan dialek dan tingkatan bahasa yang ada dalam Bahasa Madura, dan adanya berbagai korespondensi fonologis yang terjadi antara Bahasa Indonesia dan Bahasa Madura.
\end{abstract}

Alamat Korespondensi:

Nama : : Anita Rahmah Dewi ${ }^{1}$, Siti Aisah ${ }^{2}$

Instansil : Universitas Billfath

Alamat instansi : Kompleks PP Al Fattah, Desa Siman, Kecamatan Sekaran, Kabupaten Lamongan

e-mail : anitarahmahdewi92@gmail.com ${ }^{1}$, sitiaisah@billfath.ac.id ${ }^{2}$

Indonesia is well known as the country which has various cultures and also languages. Language and human in society are important components which cannot be separated. Since language, human, and society are inseparable variables, they affect each other. It means that there is no language without human and society. Language in (Sapir, 1921) is the medium for communication among communities who may have different customs, habits, and attitude. When certain language is considered to be used in a society for communication, it also mirrors a culture of the society. Thus, language is a means of communication. It plays a very important role in the human life. Its function is not only to interaction, but also to maintain the relationship among people in a community.

In Indonesia, every district has certain language; they have the uniqueness in their language variety. As Coats $(1989$, p. 4) has stated that speakers may differ in their speech because they are influenced by many types of aspects, namely age, sex, and social group. In other word, there are several factors which cause Indonesia has many language varieties and the speaker who speak in same language will make a community to keep their language. As Hudson (1980, p. 26) states that speech community is a group of people who interact by means of speech. While Hymes (1976, p. 51) points out that the same language rules includes shareknowledge of at least one language, and the knowledge of usage of the language. 
It is also strengthened by Richard $(1985$, p. 266) that speech community is a group of people who form a community, for instances, a village, a region, or a nation, and who have at least one speech variety in common.

Related to the aforementioned explanation, language variety is closely related to the speech community. Language variety is produced based on some factors, such as gender, social factor, and the other factors. While speech community is produced if there some people who have mutual intelligible in language variety. Madura is one part of Indonesia which has the unique thing in its language variety. Madurese language is interesting to be analyzed due to the various dialect which available.

There are some researchers that have observed either about Madurese language or about the ethnography of communication in the other object. The first researcher which is found is (Asy'ariy, 2003), he analyzes about the language variation and social context of male and female at the community of "Pondok Tebuireng". His analysis focuses on the different language variety which is used by male student and female student. He also applied the theory of ethnography of communication. The second researcher which is found is (Yani, 2014), he analyzes about the dialect and form of linguistic such as phonological term, morphological term, and lexical term in Kangean Island of Madura. While the last research which is found is (Azhar, 2009), his study analyzes about the absorption the vocabulary of Madurese language as the strategy of language development in Indonesia. Furthermore, this study will focus to elaborate the language variety that is available in Madurese language and phononological correspondence between Indonesian language and Madurese language by using ethnography of communication approach.

\section{METHODOLOGY}

Ethnography is a field of study which is concerned primarily by the description and analysis of culture and linguistics is a field concerned, among other things with the description and analysis of language codes. Based on the quotation above, (Hymes, 1998, p. 23) repeatedly emphasizes that what language is cannot be separated from how and why it is used, and that considerations of use are often prerequisite to recognition and understanding of much of linguistic form. While recognizing the necessity to analyze the code itself and the cognitive processes of its speakers and hearers, the ethnography of communication takes language first and foremost as a socially situated cultural form, which is indeed constitutive of much of culture itself. To accept a lesser scope for linguistic description is to risk reducing it to triviality, and to deny any possibility of understanding how language lives in the minds and on the tongues of its users.

Within each community or complex of overlapping and interacting communities there exist a number of different language codes and ways of speaking available to its members, which constitute its communicative repertoire. This includes "all varieties, dialects or styles used in a particular socially-defined population, and the constraints which govern the choice among them" (Gumperz, 1977). Any one speaker also has a variety of codes and styles from which to choose, but it is very unlikely that any individual is able to produce the full range; different subgroups of the community may understand and use different subsets of its available codes.

Identification of the varieties which occur in any community requires observation and description of actual differences in pronunciation, grammar, lexicon, styles of speaking, and other communicative behaviors which are potentially available for differentiation, but it must ultimately depend on the discovery of which differences are recognized by members of the group as conveying social meaning of some kind. In addition, the communicative repertoire of a group includes the variety of possible interaction strategies available to it. These are most commonly used to establish, maintain, or manipulate role-relationships. Speakers' choices of interaction strategies provide a dynamic connection between the language code, speakers' goals, and the participant structure in specific situations.

To achieve the aim of the research, this study employs the library research approach. It generally relies on published material, academic journals and books as well as other 
information that is available in the public domain, for example, newspapers, periodicals, magazines, and or online resources (Melrose, 2009)

As a research approach, library research is might be used to know how useful certain concepts or theories are for understanding particular patterns of behavior. Here, the focus of attention is not so much to discover something about the social world, as to reach a judgment about the value of key concepts or theories in understanding that world. In other words, how the study is approached and how contrasting approaches are drawn upon needs to be stated clearly

\section{FINDING AND DISCUSSION}

Madurese language is the local language which is spoken by Madurese ethnic to communicate each other. Either people who live in Madura Island or other small island around it. Madura Island is located in east Sea of Java Island, on $113^{\circ} \neg 115^{\circ}$ longitude west and 6, $5^{\circ} \neg 7,5^{\circ}$ southern latitude by length $90 \mathrm{~km}$ and width $40 \mathrm{~km}$ (Zainuddin, 1978). Administratively, Madura Island is divided to be four regency, they are Bangkalan, Sampang, Pamekasan, and Sumenep. Madurese people who live outside of Madura Island, mostly spread out in north beach area of East Java, such as Pasuruan, Lumajang, Probolinggo, Banyuwangi, Bondowoso, Situbondo, Jember, and others.

The spread out of using of Madurese language and the big amount of speech community, Madurese language has many varieties. It is caused by both of geographic factor and sociolinguistic factor. A language variety that is influenced by geographic factor is called dialect, while language variety that is influenced by sociolinguistic factor is like speech level.

\section{Dialect}

Basically, the amount and the various dialects in Madurese language get misconception either the native speakers or the language observers. It occurs due to the using of language approach or the different point of view in determining dialect. One side uses the original language point of view, while the other side use sociolinguistic point of view.

From the linguistic point of view, the determination of dialect is based on the original of language. When among the native speaker get the mutual intelligible in using language, they are the same speech community. In determination of dialect, when there are two speech communities which show the different characteristic of intonation, means that the language which is they used is two different dialect.

Whereas from sociolinguistic point of view, the determination of dialect is not based the original language, but based on same factors, such as history, politics, and group identification. Ray and Biswas $(2011$, p. 5) elaborate in the journal of education and practice that Dell Hymes states that "........ Speech communities cannot be defined solely through the use of linguistic criteria: the way, in which people view the language they speak is also important, that is, how they evaluate accents; how they establish the fact that they speak one language rather than another; and how they maintain language boundaries".

Based on the statement above, the dialect could not be determined only by using characteristics of linguistic. The way people attend language also the matter which is necessary to be paid attention. For example on how people attend an accent, whether they consider that the language which they use is different with the language that is used the other people, or how they determine the limitation of language. Those are the important matter which should be paid attention in determining dialect.

\subsection{Linguistics Point of View}

Based on linguistic point of view, as has been claimed by (Zainuddin, 1978) that in Madurese language there are four dialect, they are; 1.) Dialect Sumenep, 2.) Dialect Pamekasan, 3.) Dialect Bangkalan, 4.) Dialect Kangean. He also has elaborated that dialect Sumenep is used by people who live in Sumenep regency, except in some areas which is near about Pamekasan regency. Dialect Pamekasan is used by people who live in Sumenep regency in the west side, and Pamekasan regency. Dialect Bangkalan is used by people who lived in Sampang regency and 
Bangkalan regency. Dialect Kangean is used by people who live in Kangean Island that administratively included in Sumenep regency. Furthermore, the difference among those dialects is in pronunciation, especially in prosody and intonation.

Regarding to the explanation above, although Madura is divided into four regencies and many small islands, but not all the regency has special dialect, like Sampang regency still uses Bangkalan dialect. Moreover, Kangean Island which is small area has its own dialect.

The pronunciation in dialect Sumenep is marked by elongation in ultima syllable, especially in the word of vocal in the end. The pronunciation in dialect Pamekasan appropriate with the amount of its syllable, and the pronunciation in dialect Bangkalan are marked by abbreviating on vocal in the first syllable. While dialect Kangean has some differences than the other dialect, they are: a.) the pronunciation is very fast, b.) its phonological rule is different with the other dialect, c.) there are many lexical elements that are different with the other language.

1.2. Sociolinguistics Point of View

Based on sociolinguistic point of view, Madurese language is divided by two dialects, they are: 1.) Dialect Madhurâ Bârâ (west Madura) 2.) Madhurâ Témor (east Madura). Dialect Madhurâ Témor is used by people who lived in Sumenep, Situbondo, and Banyuwangi, while Madhurâ Bârâ is used by people who live in Pamekasan, Sampang, Bangkalan, Probolinggo, Pasuruan, Jember, and Bondowoso.

\section{Speech Level}

The variation of speech level in Madurese language is influenced by some factors, they are: 1.) speech event, 2.) social status, 3.) the personal relationship between the speaker and hearer, 4.) Age.

Generally, speech level in Madurese language is divided into three levels, they are: 1.) Speech level enjâ-iyâ, (EI) 2. Speech level engghi-enten (EE), and 3.) Speech level énggi-bhunten (EB). Speech level EI is kind of speech level ngoko in Java, it is used by the peer in close relationship. Speech level EE is kind of speech level karma madya in Java, it is used to communicate with the other peer but is not too close, or to the older person who has standard social status. While speech level EB is kind of speech level karma inggil in Java, it is used to communicate with the other people in formal situation, or to respect to someone.

Beside three speech levels that have been elaborated in the previous paragraph, in Madurese language also have other speech level variety which is called Bhâsa alos. This speech level is rarely used in daily communication. It is used to communicate with people who have high social status. Based the elaboration above, the speech level and its using can be seen in the following table:

Table. 1

\begin{tabular}{|c|c|c|c|c|c|c|}
\hline \multirow{2}{*}{ No } & \multirow{2}{*}{$\begin{array}{c}\begin{array}{c}\text { Speech } \\
\text { level }\end{array} \\
\end{array}$} & \multirow{2}{*}{$\begin{array}{c}\text { Personal } \\
\text { relationship }\end{array}$} & \multirow{2}{*}{ Using } & \multicolumn{3}{|c|}{ Example of using word } \\
\hline & & & & I & You & Yes \\
\hline 1. & enjâa-iyâa & $\begin{array}{l}\text { Same age, or the } \\
\text { speaker higher but } \\
\text { close relationship }\end{array}$ & $\begin{array}{l}\text { Peer, parent to their } \\
\text { children }\end{array}$ & Séngko’ & Bấna & Iyâ \\
\hline 2. & $\begin{array}{l}\text { engghi- } \\
\text { enten }\end{array}$ & $\begin{array}{l}\text { The speaker is lower } \\
\text { but the social status is } \\
\text { not too higher }\end{array}$ & $\begin{array}{l}\text { Fellow adult who is } \\
\text { just known, or to } \\
\text { our parent. }\end{array}$ & Kaulâ & sampéyan & engghi \\
\hline 3. & $\begin{array}{l}\text { énggi- } \\
\text { bhunten }\end{array}$ & $\begin{array}{l}\text { The speaker is lower } \\
\text { status, but the social } \\
\text { status is little higher }\end{array}$ & $\begin{array}{l}\text { To employer, to } \\
\text { parent in law }\end{array}$ & $\begin{array}{l}\text { Bhâdhân } \\
\text { Kaulâ }\end{array}$ & $\begin{array}{l}\text { panjenggn } \\
\text { gan }\end{array}$ & éngghi \\
\hline 4. & Bhâsa alos & $\begin{array}{l}\text { The speaker is lower } \\
\text { status, and the hearer } \\
\text { has high social status }\end{array}$ & $\begin{array}{l}\text { To teacher of islam } \\
\text { (kiai). } \\
\text { High official }\end{array}$ & $\begin{array}{l}\text { Dhâlem/ } \\
\text { abdhina }\end{array}$ & Ajunan & Dhâlem \\
\hline
\end{tabular}


KARANGAN: Jurnal Kependidikan, Pembelajaran, dan Pengembangan, Vol 03, No 01, Bulan Februari, Tahun 2021, Hal 58-66

\section{Phonological Correspondence}

The similarity and resemblance form occur in a language which is followed by the resemblance of the meaning in two languages can be proven that both of those language are interconnection. One of the forms of the similarities and resemblances in the sound system of language occur is called phonological correspondence. Although the analysis toward phonological correspondence is not luxurious issue, however, this matter is the particular thing of language which should be elaborated due to by the understanding phonological correspondence of Indonesian language and Madurese language, the learner of Madurese language could guess the meaning of difficult words in that language. The phonological correspondence between Indonesian language and Madurese language can be classified by two type, they are primer correspondence, and secondary correspondence.

3.1. Primer Correspondence

Primer Correspondence is kind of sound correspondence between two interconnection language which is relatively consistent. It occurs on almost all of vocabularies which available in both of those language. The phonological primer correspondence will be elaborated in following tables:

Table 2. The Sound [i]/[I] in Indonesian Language Become [€] in Madurese Language

\begin{tabular}{|c|c|c|c|c|c|}
\hline \multirow[t]{2}{*}{ No } & \multicolumn{2}{|c|}{ Indonesian Language } & \multirow[t]{2}{*}{ Become } & \multicolumn{2}{|c|}{ Madurese Language } \\
\hline & Form & sound & & form & Sound \\
\hline 1. & Arti & [arti] & $>$ & arté & [arte] \\
\hline 2. & Hasil & [hasIl] & $>$ & asél & [asel] \\
\hline 3. & Lima & [lima] & $>$ & léma' & [lema?] \\
\hline 4. & Lisan & [lisan] & $>$ & lésan & [lesan] \\
\hline 5. & Pilih & [pilIh] & $>$ & pélé & {$[p \epsilon l \epsilon]$} \\
\hline 6. & Siram & [siram] & $>$ & séram & [seram] \\
\hline
\end{tabular}

* The example above shows that [i] or [I] in Indonesian language that merge in except voice consonant will become $[\epsilon]$ in Madurese language.

Table 3. The Sound $[\mathrm{u}] /[\mathrm{U}]$ in Indonesian Language Become $[\mathrm{\jmath}]$ in Madurese Language

\begin{tabular}{|c|c|c|c|c|c|}
\hline \multirow{2}{*}{ No } & \multicolumn{2}{|c|}{ Indonesian Language } & \multirow{2}{*}{ Become } & \multicolumn{2}{|c|}{ Madurese Language } \\
\hline & Form & Form & & Form & Sound \\
\hline 1. & Batu & [batu] & $>$ & bât’ & [bât’] \\
\hline 2. & Kurus & [kurUs] & $>$ & Koros & [kכros] \\
\hline 3. & Luka & [luka] & $>$ & Loka & [loka] \\
\hline 4. & Sabtu & [sabtu] & $>$ & Satto & [satto] \\
\hline 5. & Susah & [susah] & $>$ & Sossa & [sวssa] \\
\hline 6. & Tunggal & [tungal] & $>$ & tongghal & [tong $\left.g^{h} \hat{a l}\right]$ \\
\hline
\end{tabular}

*The example above shows that $[\mathrm{u}]$ or $[\mathrm{U}]$ in Indonesian language that merge in voiceless consonant will become [?] in Madurese language.

Table 4. The Sound [a] in Indonesian Language Become [â] in Madurese Language

\begin{tabular}{|c|c|c|c|c|c|}
\hline \multirow[t]{2}{*}{ No } & \multicolumn{2}{|c|}{ Indonesian Language } & \multirow{2}{*}{$\begin{array}{c}\text { Become } \\
\text { Form }\end{array}$} & \multicolumn{2}{|c|}{ Madurese Language } \\
\hline & Form & Form & & Form & Sound \\
\hline 1. & Bulan & [bulan] & $>$ & Bulân & [bulân] \\
\hline 2. & Darah & [darah] & $>$ & Dârâ & [dârâ] \\
\hline 3. & Layar & [layar] & $>$ & Lajâr & [lajâr] \\
\hline 4. & Lewat & [lewat] & $>$ & Lébât & [lebât] \\
\hline 5. & Muda & [muda] & $>$ & Ngodâ & 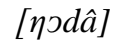 \\
\hline 6. & Wakil & [wakIl] & $>$ & Bâkkél & [bâkkєl] \\
\hline 7. & Waktu & [waktu] & $>$ & Bâkto & [bâktว] \\
\hline 8. & Wali & [wali] & $>$ & Bâlli & [bâlli] \\
\hline 9. & Warung & 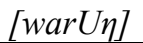 & $>$ & Bârung & [bâruך] \\
\hline
\end{tabular}


KARANGAN: Jurnal Kependidikan, Pembelajaran, dan Pengembangan, Vol 03, No 01, Bulan Februari, Tahun 2021, Hal 58-66

*The example above shows that [a] in Indonesian language that merge in voice consonant or semi- vowel, lateral, and vibration in the previous syllable ia voice consonant will become [â] in Madurese language.

Table 5. The Sound [w] in Indonesian Language Become [b] in Madurese Language

\begin{tabular}{|c|c|c|c|c|c|}
\hline \multirow[t]{2}{*}{ No } & \multicolumn{2}{|c|}{ Indonesian Language } & \multirow[t]{2}{*}{ Become } & \multicolumn{2}{|c|}{ Madurese Language } \\
\hline & Form & sound & & form & Sound \\
\hline 1. & Kawin & [kawin] & $>$ & Kabin & [kabin] \\
\hline 2. & Lewat & [lewat] & $>$ & Lébât & {$[l \epsilon b \hat{a} t]$} \\
\hline 3. & Wakil & [wakIl] & $>$ & Bâkkél & [bâkkєl] \\
\hline 4. & Waktu & [waktu] & $>$ & Bâkto & [bâkto] \\
\hline 5. & Warug & [warUn] & $>$ & Bârung & [bâru१] \\
\hline 6. & Wasiat & [wasiyat] & $>$ & Bâséyat & [bâseyat] \\
\hline
\end{tabular}

*The example above shows that $[\mathrm{w}]$ in Indonesian language that is phoneme will become [b] in Madurese language.

Table 5. The Sound [t\#] in Indonesian Language Become [?] in Madurese Language

\begin{tabular}{|c|c|c|c|c|c|}
\hline \multirow[t]{2}{*}{ No } & \multicolumn{2}{|c|}{ Indonesian Language } & \multirow[t]{2}{*}{ Become } & \multicolumn{2}{|c|}{ Madurese Language } \\
\hline & Form & Sound & & form & Sound \\
\hline 1. & Barat & [barat] & $>$ & bârâ' & [bârâa?] \\
\hline 2. & Ketupat & [ketupat] & $>$ & katopa' & [katspa?] \\
\hline 3. & Langit & [lanit] & $>$ & langngé' & 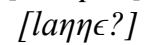 \\
\hline 4. & Sakit & [sakIt] & $>$ & sake' & [sak€?] \\
\hline
\end{tabular}

*The example above shows that $[\mathrm{t}]$ in Indonesian language that exist in the end of word will become [?] in Madurese language.

Table 6. The Sound $[\mathrm{h}]$ in Indonesian Language Become $[\Theta]$ in Madurese Language

\begin{tabular}{cccccc}
\hline No & \multicolumn{2}{c}{ Indonesian Language } & Become & \multicolumn{2}{c}{ Madurese Language } \\
& Form & Sound & & form & Sound \\
\hline 1. & Kalah & [kalah] & $>$ & Kala & [kala] \\
2. & Lumpuh & [lumpUh] & $>$ & Lompo & [lompo] \\
3. & Lurah & [lurah] & $>$ & Lora & [lora] \\
4. & Putih & [puth] & $>$ & Poté & [pott] \\
5. & Rumah & [rumah] & $>$ & Roma & [roma] \\
6. & Salah & [salah] & $>$ & Sala & [sala] \\
7. & Sawah & [sawah] & $>$ & Sabâ & {$[$ sabâa] } \\
8. & Tanah & [tanah] & $>$ & Tana & [tana] \\
\hline
\end{tabular}

*The example above shows that $[\mathrm{h}]$ in Indonesian language that exist in the end of word will become $[\Theta]$, or in other word it is omitting $[\mathrm{h}]$ in Madurese language.

\subsection{Secondary Correspondence}

\subsubsection{Lenisi}

Lenisi is the dilution that occurs in Madurese language, they are: apokope, sinkope, kompresi, while reduction consonant group and haplogi is not occurred. The dilution sound occur in the sound [d]in Indonesian language become [1] in Madurese language.

Table 7. apokope

\begin{tabular}{|c|c|c|c|c|c|}
\hline \multirow[t]{2}{*}{ No } & \multicolumn{2}{|c|}{ Indonesian Language } & \multirow[b]{2}{*}{ Process } & \multicolumn{2}{|c|}{ Madurese Language } \\
\hline & Form & Sound & & form & Sound \\
\hline 1. & Adik & [adI?] & {$[d]>[l]>[$ all? $] ;[I]>[\epsilon]$} & alé' & [ale?] \\
\hline 2. & Hidung & [hidU & $\begin{array}{c}{[h]>[\Theta]>[i d U \eta] ;} \\
{[d]>[l]>[i l U \eta] ;[U]>[\supset]}\end{array}$ & élong & {$[\epsilon l \supset \eta]$} \\
\hline 3. & Lidah & [lidah] & {$[h]>[\Theta]>[$ lida $]>[$ lila $]>[$ lilâa $]$} & jhilâ & {$\left[j^{h} i l \hat{a}\right]$} \\
\hline
\end{tabular}


KARANGAN: Jurnal Kependidikan, Pembelajaran, dan Pengembangan, Vol 03, No 01, Bulan Februari, Tahun 2021, Hal 58-66

The other form of lenisi that occur in Madurese language is sinkope and kompresi. Sinkope is the deletion of vowel sounds in middle word, while compression is the process of deletion syllable. Those examples will be elaborated in following table:

Table 8. Sinkope

\begin{tabular}{cccccc}
\hline No & \multicolumn{2}{c}{ Indonesian Language } & \multirow{2}{c}{ Process } & \multicolumn{2}{c}{ Madurese Language } \\
& Form & Sound & form & Sound \\
\hline 1. & Di mana & {$[$ di mana $]$} & {$[a]>[\Theta]>[$ dimna $]$} & dimma & {$[$ dimma $]$} \\
2. & Keliling & {$[$ kelillin] } & {$[a]>[\Theta]$} & kléléng & {$[$ klelen] } \\
3. & Siapa & {$[$ siapa $]$} & {$[i]>[\Theta]$} & sapa & {$[$ sapa] }
\end{tabular}

Table 9. Kompresi

\begin{tabular}{cccccc}
\hline No & \multicolumn{2}{c}{ Indonesian Language } & \multirow{2}{*}{ Process } & \multicolumn{2}{c}{ Madurese Language } \\
& Form & Sound & form & Sound \\
\hline 1. & Matahari & {$[$ matahari $]$} & {$[$ mata $]>[\Theta]>[$ hari $]$} & aré & {$[$ are $]$} \\
2. & Seratus & {$[$ seratUs $]$} & {$[$ ra $]>[\Theta]>[$ satUs $]$} & satos & {$[$ satos $]$}
\end{tabular}

\subsubsection{Sound Affirmation}

This following table is the example of phonological correspondence by strengthens the sound between Indonesian language and Madurese language.

Table. 10

\begin{tabular}{|c|c|c|c|c|c|}
\hline \multirow[t]{2}{*}{ No } & \multicolumn{2}{|c|}{ Indonesian Language } & \multirow{2}{*}{ Process } & \multicolumn{2}{|c|}{ Madurese Language } \\
\hline & Form & Sound & & form & Sound \\
\hline 1. & Balik & [ball?] & {$[?]>[k]$} & bhâlik & [b $b^{h} \hat{a l i k]}$ \\
\hline 2. & Itik & [itI?] & {$[?]>[\mathrm{k}]$} & éték & {$[\epsilon t \in k]$} \\
\hline 3. & Lirik & [lirI?] & {$[?]>[\mathrm{k}]$} & lérék & [lerek] \\
\hline 4. & Pipih & [pipIh] & {$[h]>[?]$} & ре́рре́ & [рєррє?] \\
\hline
\end{tabular}

\subsubsection{Sound Addition}

The phonological correspondence by addition sound occur in Madurese language, they are protesis, the addition of sound glottal in the end of word, diphthongization vowel in the end of word,gemination, and aspiration. This following table will elaborate the five kinds of Sound addition.

Table 11. Protesis

\begin{tabular}{|c|c|c|c|c|c|}
\hline \multirow[t]{2}{*}{ No } & \multicolumn{2}{|c|}{ Indonesian Language } & \multirow{2}{*}{ Become } & \multicolumn{2}{|c|}{ Madurese Language } \\
\hline & Form & Sound & & form & Sound \\
\hline 1. & Bor & [bor] & $>$ & ebbur & {$[a b b U r]$} \\
\hline 2. & Cat & [cat] & $>$ & eccét & {$[\partial c c \in t]$} \\
\hline 3. & Gong & [gวク] & $>$ & egghung & {$\left[a g g^{h} u \eta\right]$} \\
\hline
\end{tabular}

*Protesis is the addition sound either in vowel or consonant in beginning word.

Table 12. The Addition of Glotal Sound in the End of Word

\begin{tabular}{cccccc}
\hline No & \multicolumn{2}{c}{ Indonesian Language } & \multirow{2}{*}{ Become } & \multicolumn{2}{c}{ Madurese Language } \\
& Form & Sound & form & Sound \\
\hline 1. & Dua & [duwa] & $>$ & duwấ, & [duwâ??] \\
2. & Lima & [lima] & $>$ & léma' & [lema?]
\end{tabular}

Table 13. Vocal Diphthongization in the End of Word

\begin{tabular}{cccccc}
\hline No & \multicolumn{2}{c}{ Indonesian Language } & \multirow{2}{*}{ Become } & \multicolumn{2}{c}{ Madurese Language } \\
& Form & Sound & $>$ & apoy & Sound \\
\hline 1. & Api & [api] & $>$ & tapoys \\
2. & Tamu & [tamu] & $>$ & tapay & [tamyay] \\
3. & Tape & [tape] & $>$ & toroy & [toroy] \\
\hline
\end{tabular}


KARANGAN: Jurnal Kependidikan, Pembelajaran, dan Pengembangan, Vol 03, No 01, Bulan Februari, Tahun 2021, Hal 58-66

Table 14. Gemination

\begin{tabular}{|c|c|c|c|c|c|}
\hline \multirow[t]{2}{*}{ No } & \multicolumn{2}{|c|}{ Indonesian Language } & \multirow{2}{*}{ Become } & \multicolumn{2}{|c|}{ Madurese Language } \\
\hline & Form & Sound & & form & Sound \\
\hline 1. & Bor & [bor] & $>$ & ebbur & [abbUr] \\
\hline 2. & Cat & [cat] & $>$ & eccét & {$[\partial c c \epsilon t]$} \\
\hline 3. & Gong & 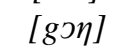 & $>$ & egghung & {$\left[\partial g g^{h} u \eta\right]$} \\
\hline 4. & Langit & [lanit] & $>$ & Langngé' & 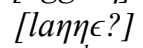 \\
\hline 5. & Lebat & [lebbat] & $>$ & Lebbâ' & [labb $\left.b^{h} \hat{a} ?\right]$ \\
\hline 6. & Pipih & [pipIh] & $>$ & ре́pрé & [рєррє?] \\
\hline 7. & Wakil & [wakIl] & $>$ & bakkél & [bâkkєl] \\
\hline 8. & Wali & [wali] & $>$ & bâlli & [bâlli] \\
\hline
\end{tabular}

Table 15. Aspiration

\begin{tabular}{|c|c|c|c|c|c|}
\hline \multirow[t]{2}{*}{ No } & \multicolumn{2}{|c|}{ Indonesian Language } & \multirow{2}{*}{ Become } & \multicolumn{2}{|c|}{ Madurese Language } \\
\hline & Form & Sound & & form & Sound \\
\hline 1. & Bagus & [bagUs] & $>$ & bhâghus & {$\left[b^{h} \hat{a} g^{h} u s\right]$} \\
\hline 2. & Bakal & [bakal] & $>$ & bhâkal & {$\left[b^{h} \hat{a k a l}\right]$} \\
\hline 3. & Bangsa & [bansa] & $>$ & bhângsa & {$\left[b^{h} \hat{a} \eta s a\right]$} \\
\hline 4. & Baru & [baru] & $>$ & bhuru & {$\left[b^{h} u r u\right]$} \\
\hline 5. & Bosan & [bosan] & $>$ & bhusen & [b $\left.b^{h} u s \partial n\right]$ \\
\hline 6. & Gong & {$[g \ni \eta]$} & $>$ & egghung & [agg ${ }^{h}$ ung \\
\hline 7. & Lebat & [labat] & $>$ & lebbhâ' & {$\left[l a b b^{h} \hat{a}\right]$} \\
\hline 8. & Tunggal & [tungal] & $>$ & tongghâl & [tong ${ }^{h} \hat{a l l}$ \\
\hline
\end{tabular}

Table 16. Metathesis

\begin{tabular}{|c|c|c|c|c|c|}
\hline \multirow[t]{2}{*}{ No } & \multicolumn{2}{|c|}{ Indonesian Language } & \multirow[b]{2}{*}{ Process } & \multicolumn{2}{|c|}{ Madurese Language } \\
\hline & Form & Sound & & form & Sound \\
\hline 1. & Lutut & [lutUt] & $\begin{array}{c}{[t]=[I]>[t u l U t]>[t u U t]>} \\
{[t \supset \supset t]>}\end{array}$ & to'ot & {$[t \supset ? J t]$} \\
\hline 2. & Rampok & [rampsk] & {$[a]=[\supset]>$} & rompak & [rэmpak] \\
\hline 3. & Sobek & [sobe?] & {$[\supset]=[\epsilon]>[s \epsilon b \supset ?]>$} & sébâ' & [ séb??] \\
\hline 4. & Tanam & [tanam] & {$[n]=[m]>[$ taman $]>$} & tamen & [tamən] \\
\hline 5. & Tangan & [tanan] & {$[n]=[\eta]>$} & tanang & 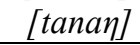 \\
\hline
\end{tabular}

Methatesis is kind of the changing of sound by exchange phoneme position. Methatesis is kind of the changing of sound by exchange phoneme position. Based on table above, it can be indicated that metathesis in phonology is such transposition of sound or syllable in word in sentence. In Madurese Language, this circumstance is often happened in exchanging phoneme position, as some examples that have been shown above.

Table.17 Assimilation

\begin{tabular}{|c|c|c|c|c|c|}
\hline \multirow[t]{2}{*}{ No } & \multicolumn{2}{|c|}{ Indonesian Language } & \multirow{2}{*}{ Process } & \multicolumn{2}{|c|}{ Madurese Language } \\
\hline & Form & Sound & & form & Sound \\
\hline 1. & Belalang & [balalang] & {$[a]>[\hat{a}]>[$ bolla $]>$} & bâllâng & [bâllầ] \\
\hline 2. & Di mana & [di mana] & {$[n]>[m]>[$ dimna $]>$} & dimma & [dimma] \\
\hline 3. & Ke mana & [kəmana] & {$[n]>[\mathrm{m}]>[$ kəmna $]$} & kemma & [kəmma] \\
\hline
\end{tabular}

*Assimilation is kind of the changing of sound by the adaptation of sound from the different sound to be mutual sound.

\section{CONCLUSION}

To sum up, language and society is the inseparable variable which cannot be separated. They affect each other. It is realize or not, in line on the development era, language variety is formed through some factors. Madura is part of Indonesian country which has many language varieties. In those varieties, it is found that there are some dialects which exist in Madurese language. Based linguistic point of view, there are four dialects; Dialect Sumenep, dialect Pamekasan, dialect Bangkalan, and dialect Kangean. While based on sociolinguistic point of view, there are two dialects; Dialect Madhurâ Bârâ (west Madura) and Madhurâ Témor (east 
KARANGAN: Jurnal Kependidikan, Pembelajaran, dan Pengembangan, Vol 03, No 01, Bulan Februari, Tahun 2021, Hal 58-66

Madura). Then, in Madurese language also include some speech level in communication, they are; enjâ-iyâ, engghi-enten, énggi-bhunten, Bhâsa alo. Besides, there are some phonological correspondences which occur between Indonesian language and Madurese language. They are primer correspondence and secondary correspondence.

\section{REFERENCES}

Asy'ariy. (2003). Language Variation and Social Context of Male and Female speakers at the Community of "Pondok Pesantren Tebuireng". Universitas Negeri Surabaya, Surabaya.

Azhar, Iqbal Nurul. (2009). Bahasa dan Sastra dalam Kearifan Lokal: Penyerapan Kosakata Bahasa Madura Sebagai Pelestarian dan Pengembangan Bahasa Indonesia. Surabaya: Kanzun.

Coats, Jennifer. (1989). Women, Men, and Language. London: Longman Group.

Gumperz. (1977). Directions in Sociolinguistics: The Ethnography of Communication. New York: Holt, Rinehart \& Winston.

Hudson, R.A. (1980). Sociolinguistics. Cambridge: Cambridge University press.

Hymes, Dell. (1976). Foundation of Sociolinguistics: An Ethnographic Approach. Philadelphia: University of Pensylvania.

Hymes, Dell. (1998). Ethnography, Linguistics, Narrative Inequality Toward an Understanding of Voice. London: Taylor and Francis Ltd.

Melrose, Dr. M. (2009). Ethical Guidance for Library Based Research. www.the-sra.org.uk Ray, Dr. Manas, \& Biswas, Mr. Chinmay. (2011). A study on Ethnography of communication: A discourse analysis with Hymes 'speaking model' Journal of Education and Practice 2 .

Richard, Jack. (1985). Longman Dictionary of Applied Linguistics. London: Longman.

Sapir, Edward. (1921). Language: An Introduction to the Study of Speech. United States of America: Harcourt, Brace and World, Inc.

Saville, Muriel. (2003). Ethnography of Communication Oxford: Blackwell publishing.

Yani, Ahmad. (2014). Bahasa Madura di Kepulauan Kangean. Universitas Negeri Surabaya, Surabaya.

Zainuddin, et al. (1978). Bahasa Madura. Jakarta: Pusat Pembinaan dan Pengembangan bahasa, Depdikbud. 